\title{
NUMERICAL STUDY OF A FLOW OF VISCOELASTIC FLUID OF KELVIN-VOIGT HAVING ZERO ORDER IN A MAGNETIC FIELD
}

\section{S. I. Kadchenko, Nosov Magnitogorsk State Technical University, Magnitogorsk,} Russian Federation, kadchenko@masu.ru,

A. O. Kondyukov, Yaroslav-the-Wise Novgorod State University, Veliky Novgorod, Russian Federation, k.a.o_leksey999@mail.ru.

The article developed algorithms for the numerical solution of the initial - boundary problem of the flow of an incompressible viscoelastic Kelvin-Voigt fluid in the Earth's magnetic field. The theorem on an existence and uniqueness of this problem solution is proved using the theory of semilinear Sobolev type equations in the works written by T.G. Sukachev, S.A. Kondyukova. The original initial-boundary problem is transformed to the Cauchy problem for ordinary systems of nonlinear equations by sampling. Algorithms based on the explicit one-step schemes having Runge-Kutta type of seventh-order accuracy with a choice of integration step are used to find a numerical solution of the Cauchy problem. Evaluation of control of calculation accuracy at each time step is carried out by a scheme of the eighth order of accuracy. A time step is chosen according to the results of monitoring. Computational experiments show high computational efficiency of the developed algorithms for solving of the problem considered.

Keywords: magnetohydrodynamics, incompressible viscoelastic fluid, explicit one-step formulas of Runge-Kutta, Sobolev type equations.

\section{Introduction}

Consider the initial-boundary problem of the flow of an incompressible viscoelastic fluid of Kelvin-Voigt of zero-order [1] in the Earth's magnetic field. These problems occur in geophysics in the study of electrically conducting fluid rotation process in a magnetic field of the Earth [2].

$$
\begin{gathered}
(1-\chi \triangle) v_{t}=\nu \triangle v-(v \cdot \nabla) v-\frac{1}{\rho} \nabla p-2 \Omega \times v+\frac{1}{\rho \mu}(\nabla \times b) \times b, \\
\nabla v=0, \quad \nabla b=0, \quad b_{t}=\delta \triangle b+\nabla \times(v \times b), \\
v(x, 0)=v_{0}(x), \quad b(x, 0)=b_{0}(x), \quad x \in D, \\
v(x, t)=0, \quad b(x, t)=0, \quad(x, t) \in \partial D \times R_{+} .
\end{gathered}
$$

Here, the vector-functions $v$ and $b$ determine a velocity of fluid and an induction of a magnetic field, respectively, $p$ is hydrodynamic pressure, $\chi$ is fluid elasticity coefficient, $\Omega=\frac{1}{2} \nabla \times v$ is angular velocity of fluid rotation, $\nabla$ is Hamilton operator, $\delta$ is magnetic fluid viscosity, $\mu$ is magnetic permeability of fluid, $\rho$ is density of fluid, $D \in R^{2}$ is cylindrical domain with boundary $\partial D$ of $C^{\infty}$ class.

Earlier, the initial-boundary problems for magnetohydrodynamics models were studied in $[3,4,5]$ in the theory of semilinear Sobolev type equations [6]. Theorems on the existence and uniqueness of solutions of such problems are proved in these works. 


\section{Method of solving}

Exclude from the first equation (1) hydrodynamic pressure $p$. To this end set

$$
v=\nabla \times \psi
$$

Substitute (4) in (1). We have

$$
\begin{gathered}
(1-\chi \triangle) \nabla \times \psi_{t}=\nu \triangle(\nabla \times \psi)-((\nabla \times \psi) \cdot \nabla) \nabla \times \psi- \\
-\frac{1}{\rho} \nabla p-2 \Omega \times \nabla \times \psi+\frac{1}{\rho \mu}(\nabla \times b) \times b .
\end{gathered}
$$

Here $2 \Omega=\nabla \times(\nabla \times \psi)=\nabla(\nabla \cdot \psi)-\Delta \psi$.

Apply the operation rot to equation (5). Taking into account that $\nabla \times \nabla p \equiv 0$, we find

$$
\begin{gathered}
\nabla \times\left[(1-\chi \Delta) \nabla \times \psi_{t}\right]=\nu \nabla \times[\Delta(\nabla \times \psi)]- \\
-\nabla \times\left[((\nabla \times \psi) \cdot \nabla) \nabla \times \psi+2 \Omega \times \nabla \times \psi-\frac{1}{\rho \mu}(\nabla \times b) \times b\right] .
\end{gathered}
$$

Using the rules of action with the operator $\nabla$, we write

$$
\nabla \times \nabla \times \psi=\nabla(\nabla \cdot \psi)-\triangle \psi
$$

Then

$$
\nabla \times \triangle(\nabla \times \psi)=\nabla \times \Delta(\nabla \times \psi)=\nabla[\Delta(\nabla \cdot \psi)]-\triangle^{2} \psi
$$

and the equation (6) takes the form

$$
\begin{gathered}
\nabla\left(\nabla \cdot \psi_{t}\right)-\Delta \psi_{t}-\chi\left[\nabla\left(\Delta\left(\nabla \cdot \psi_{t}\right)\right)-\Delta^{2} \psi_{t}\right]= \\
=\nu\left[\nabla(\Delta(\nabla \cdot \psi))-\Delta^{2} \psi\right]-\nabla \times[((\nabla \times \psi) \cdot \nabla) \nabla \times \psi+ \\
\left.+(\nabla \times(\nabla \times \psi)) \times \nabla \times \psi-\frac{1}{\rho \mu}(\nabla \times b) \times b\right] .
\end{gathered}
$$

Note that $\nabla b=0$. Therefore vector $b$ can be written as

$$
b=\nabla \times A .
$$

Vector-function $A$ is called a vector potential of magnetic field.

In view of the above we write the following initial-boundary problem, which is equivalent to $(1)-(3)$ :

$$
\begin{gathered}
\frac{\partial B(\psi)}{\partial t}=C(\psi, A), \\
\frac{\partial G(A)}{\partial t}=M(\psi, A), \\
v=\nabla \times \psi, \quad b=\nabla \times A . \\
\nabla \times \psi(x, 0)=v_{0}(x), \quad \nabla \times A(x, 0)=b_{0}(x), \quad x \in D,
\end{gathered}
$$




$$
\nabla \times \psi(x, t)=0, \quad \nabla \times A(x, t)=0, \quad(x, t) \in \partial D \times R_{+},
$$

where the vector-differential expressions included in (8) have the form:

$$
\begin{gathered}
B(\psi) \equiv \nabla(\nabla \cdot \psi)-\Delta \psi-\chi\left[\nabla(\Delta(\nabla \cdot \psi))-\triangle^{2} \psi\right] \\
C(\psi, A) \equiv \nu\left[\nabla(\Delta(\nabla \cdot \psi))-\triangle^{2} \psi\right]- \\
-\nabla \times[((\nabla \times \psi) \cdot \nabla) \nabla \times \psi+(\nabla \times(\nabla \times \psi)) \times \nabla \times \psi]+ \\
+\frac{1}{\rho \mu} \nabla \times[(\nabla(\nabla \cdot A)-\triangle A) \times(\nabla \times A)], \\
G(A) \equiv \nabla \times A, \\
M(\psi, A) \equiv \nabla \times[(\nabla \times \psi) \times(\nabla \times A)] .
\end{gathered}
$$

Introduce a cylindrical coordinate system $(r, \varphi, z)$ with center $O$ on one of the side surfaces of the cylinder $D$ and combine $O z$ axis with the cylinder axis. In the future, we will assume that a flow of fluid is axially symmetric.

\section{Computing experiment}

We carry out a sampling by finite difference method [7]. Transform the system of differential equations in partial derivatives (8) into the system of ordinary differential equations in time. To this end, consider a set of points $D_{h_{r}, h_{z}}=\left\{\left(r_{i}, \varphi_{0}, z_{k}\right)\right\}, D_{h_{r}, h_{z}} \in D$, $i=\overline{1, N_{r}}, k=\overline{1, N_{z}}$ in a domain of research $D$ in a section $\varphi=\varphi_{0}$. Here $h_{r}, h_{z}$ define uniform steps of sampling grid along the corresponding axes of a cylindrical coordinate system. Let $r_{0}$ be a radius of cylinder, and $z_{0}$ be its length. Then finite difference analogue of the initial-boundary problem (8) - (10) can be written as:

$$
\begin{gathered}
\frac{d \widehat{Y}\left(\psi_{i k}(t), A_{i k}(t)\right)}{d t}=\widehat{F}\left(\psi_{i k}(t), A_{i k}(t)\right), \\
v_{i k}(t)=\widehat{G}\left(\psi_{i k}(t)\right), \quad b_{i k}(t)=\widehat{G}\left(A_{i k}(t)\right), \\
\widehat{G}\left(\psi_{i k}(0)\right)=v_{0}\left(r_{i}, z_{k}\right), \\
\widehat{G}\left(A_{i k}(0)\right)=b_{0}\left(r_{i}, z_{k}\right), \quad\left(r_{i}, \varphi_{0}, z_{k}\right) \in D, \\
\widehat{G}\left(\psi_{i k}(t)\right)=0, \quad \widehat{G}\left(A_{i k}(t)\right)=0, \quad\left(r_{i}, \varphi_{0}, z_{k}, t\right) \in \partial D \times R_{+} .
\end{gathered}
$$

Here

$$
\begin{aligned}
\widehat{Y}\left(\psi_{i k}(t), A_{i k}(t)\right) & =\left(\begin{array}{c}
\widehat{B}\left(\psi_{i k}(t)\right) \\
\widehat{G}\left(\psi_{i k}(t), A_{i k}(t)\right)
\end{array}\right), \\
\widehat{F}\left(\psi_{i k}(t), A_{i k}(t)\right) & =\left(\begin{array}{c}
\widehat{C}\left(\psi_{i k}(t), A_{i k}(t)\right) \\
\widehat{M}\left(\psi_{i k}(t), A_{i k}(t)\right)
\end{array}\right),
\end{aligned}
$$


$\psi_{i k}(t)=\psi\left(r_{i}, z_{k}, t\right), A_{i k}(t)=A\left(r_{i}, z_{k}, t\right), \widehat{B}\left(\psi_{i k}(t)\right), \widehat{C}\left(\psi_{i k}(t), A_{i k}(t)\right), \widehat{G}\left(A_{i k}(t)\right)$, $\widehat{M}\left(\psi_{i k}(t), A_{i k}(t)\right)$ are finite difference analogues of expressions $B(\psi), C(\psi, A), G(A)$, $M(\psi, A)$, respectively.

To find grid expressions $\widehat{B}\left(\psi_{i k}(t)\right), \widehat{C}\left(\psi_{i k}(t), A_{i k}(t)\right), \widehat{G}\left(A_{i k}(t)\right), \widehat{M}\left(\psi_{i k}(t), A_{i k}(t)\right)$ it is necessary to approximate the derivatives up to the fourth order. To this end a programm is written in Maple mathematical software. This programm allow to find the coefficients in the algebraic formulas of approximation of derivatives having proper order, using the given number of node points, and to determine the order of their approximation accuracy.

The numerical solution of the Cauchy problem (13) - (15) is found by algorithms of explicit one-step formulas having Runge-Kutta type [8]

$$
\begin{gathered}
\widehat{Y}_{n+1}=\widehat{Y}_{n}+\sum_{i=1}^{13} p_{m i} k_{i}, \\
k_{i}=h \widehat{F}\left(t_{n}+\alpha_{i} h_{t}, \psi_{n}+\sum_{j=1}^{13} \beta_{i j} k_{j}, A_{n}+\sum_{j=1}^{13} \beta_{i j} k_{j}\right),
\end{gathered}
$$

here $h_{t}$ is an integration step of the Runge-Kutta method. The values of coefficients $\alpha_{i}$, $\beta_{i j}$ are taken from the paper [8].

One can use explicit methods for solving of the stiff problems. Then an integration step is limited both by an accuracy of calculations and a stability of the numerical scheme [8]. Local error $\delta_{n}$ of method of seventh order is calculated by the formula [8]

$$
\delta_{n}=\sum_{i=1}^{13}\left(p_{8 i}-p_{7 i}\right) k_{i}
$$

where the coefficients $p_{8 i}$ are

$$
\begin{gathered}
p_{81}=p_{82}=p_{73}=p_{74}=p_{75}=0, p_{76}=\frac{34}{105}, p_{87}=p_{88}=\frac{9}{35}, \\
p_{89}=p_{8,10}=\frac{9}{280}, p_{8,11}=p_{8,12}=0, p_{8,13}=\frac{41}{840} .
\end{gathered}
$$

To evaluate a control of accuracy of the calculations the following inequality is used:

$$
\left\|\delta_{n}\right\| \leq \varepsilon
$$

Here $\|\cdot\|$ is a norm in $R^{J}, J$ is a dimension of column matrix $F(t, U(t)), \varepsilon$ is a required accuracy of calculations. In this case, $\delta_{n}=O\left(h_{t}^{8}\right)$. Therefore, the integration step $h^{a c}$ is calculated by the formula[8]

$$
h^{a c}=q h_{t}, q=\sqrt[8]{\frac{\varepsilon}{\left\|\delta_{n}\right\|}} .
$$

If $q<1$, then the calculations obtained in step $h_{t}$ are repeated at step $h^{a c}$. Otherwise, calculations are continued at the next time interval.

Figures $1-3$ show the charts of surfaces of fluid flow velocity components at time $t_{*}=3 \mathrm{~s}$., obtained for the following values of the problem parameters: $\chi=2,7 \mathrm{~m} / \mathrm{s}^{2}$, $\nu=0,00328 \mathrm{~m}^{2} / \mathrm{c}, \mu=1 \rho=1000 \mathrm{~kg} / \mathrm{m}^{3}, \delta=0,1, r_{0}=0,1 \mathrm{~m}, z_{0}=0,2 \mathrm{~m}$. Vector functions $v_{0}(r, z)$ and $b_{0}(r, z)$ in the initial conditions $(2)$ are given in the form $v_{0}=\omega_{0} r i_{r}$, 
$b_{0}=b_{r_{0}} i_{r}$, where $\omega_{0}=0,251 / \mathrm{s}, b_{r_{0}}=0,00005 \mathrm{~T}$. The initial conditions for vectorfunctions $\psi, A$ are given in the form $\psi(r, z, 0)=0,25 \omega_{0} r\left(2 z i_{r}-r i_{z}\right), A(r, z, 0)=-b_{r_{0}} z i_{\varphi_{\varphi}}$. The boundary and initial conditions for vector-functions $\psi$ and $A$ are given in the form: $\psi(r, z, t)=0, \quad A(r, z, t)=0,(x, r, t) \in \partial D \times R_{+}$.

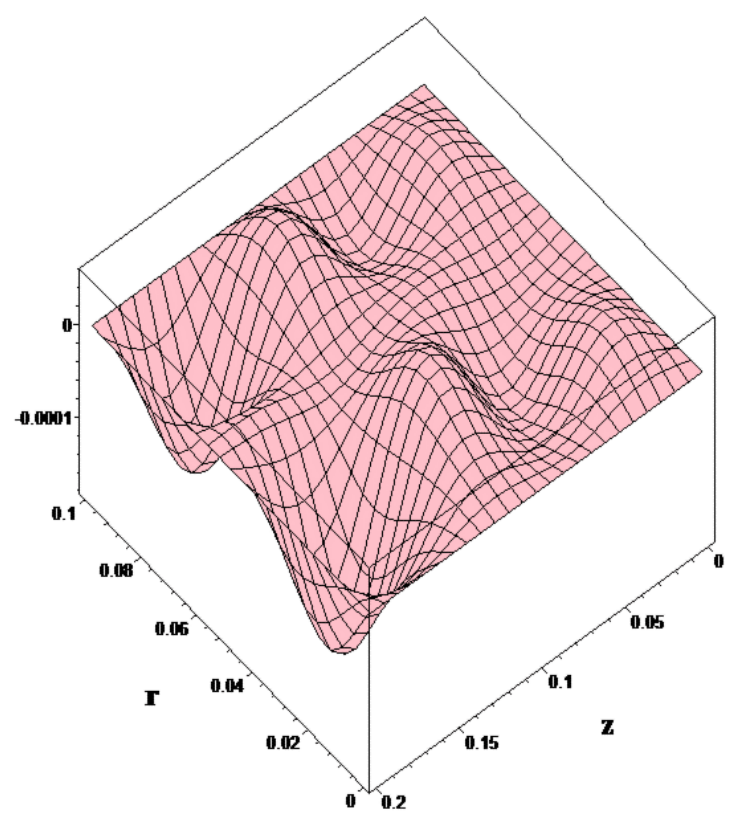

Fig. 1. Chart of surface of radial component of fluid flow velocity $v_{r}=v_{r}\left(r, z, t_{*}\right)(\mathrm{m} / \mathrm{s})$ at the time $t_{*}=3 \mathrm{~s}$.

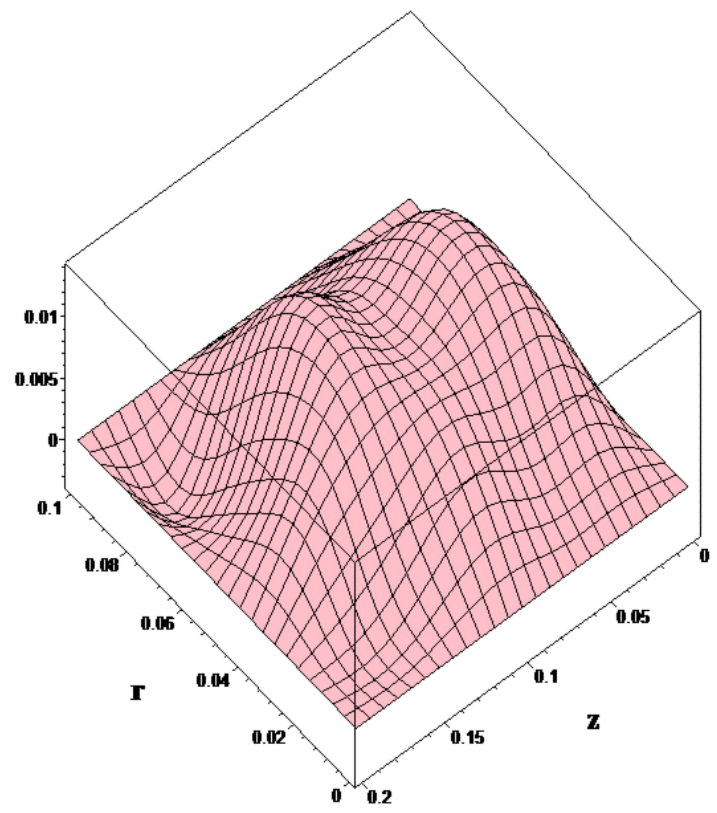

Fig. 2. Chart of surface of transversal component of fluid flow velocity $v_{\varphi}=v_{\varphi}\left(r, z, t_{*}\right)(\mathrm{m} / \mathrm{s})$ at the time $t_{*}=3 \mathrm{~s}$. 


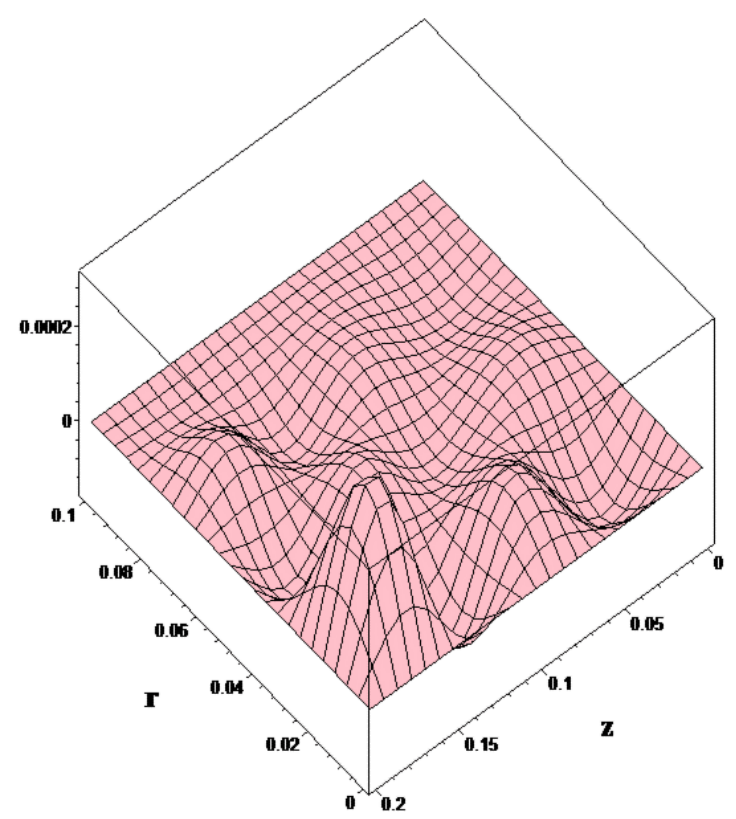

Fig. 3. Chart of surface of axial component of fluid flow velocity $v_{z}=v_{z}\left(r, z, t_{*}\right)(\mathrm{m} / \mathrm{s})$ at the time $t_{*}=3 \mathrm{~s}$.

Conducted computing experiments show a computational stability of the developed algorithm for numerical solution of the initial-boundary problem (1) - (3).

\section{References}

1. Oskolkov A.P. Initial-Boundary Problems for the Equations of Fluid Movement of Kelvin-Voigt and Oldroyd. Tr. Mat. Inst. im. V.A. Steklova Akad. Nauk SSSR - Proceedings of the Steklov Mathematical Institute USSR AS, 1988, vol. 179, pp. 126-164. (in Russian)

2. Hide R. On Planetary Atmospheres and Interiors. Mathematical Problems in the Geophisical Sciences. V. 1. Providence R.I., AMS, 1971.

3. Sukacheva T.G., Kondyukov A.O. The Phase Space of a Problem of Magnetohydrodynamics. Differential Equations, 2015, vol. 51, no. 4, pp. 495-501. doi: 10.1134/S037406411504007X

4. Kondyukov A.O., Sukacheva T.G. On a Model of Magnetohydrodynamics of Nonzero Order. XVI Vserossijskij simpozium po prikladnoj $i$ promyshlennoj matematike, letnjaja sessija. Cheljabinsk, 21 - 27 ijunja 2015. - XVI All-Russian Symposium on Applied and Industrial Mathematics, summer session. Chelyabinsk, on June 21 - 27, 2015. Chelyabinsk, 2015, p. 75. (in Russian)

5. Kondyukov S.A. Quasistationary Semitrajectory for Generalized Model of Magnetohydrodynamics. Mezhdunarodnaja konferencija "Matematika $i$ informacionnye tehnologii $v$ neftegazovom komplekse posvjashhennaja dnju rozhdenija velikogo russkogo matematika akademika P.L. Chebysheva. Surgut, 16 - 20 maja 
2016. - International Conference "Mathematics and Information Technology in the Oil and Gas Industry", Dedicated to the Birthday of the Great Russian Mathematician, Academician P.L. Chebysheva. Surgut, on May 16 - 20. Surgut, 2016, p. 47. (in Russian)

6. Matveeva O.P., Sukacheva T.G. Mathematical Models of Viscoelastic Incompressible Fluids of Nonzero Order. Chelyabinsk, Publishing Center of the South Ural State University, 2014. (in Russian)

7. Fletcher C. Computational Techniques for Fluid Dynamics. Vol. 2. Berlin, Heidelberg, Springer-Verlag, 1991. doi: 10.1007/978-3-642-58239-4

8. Novikov E.A. Algorithms of Variable Structure Development for the Solving of the Stiff Problems. Krasnoyarsk, 2014. (in Russian)

Sergey I. Kadchenko, Doctor of Physico-Mathematical Sciences, Professor, Department of Applied Mathematics and Computer Science, Magnitogorsk State Technical University (Magnitogorsk, Russian Federation), kadchenko@masu.ru

Aleksey O. Kondyukov, Post-Graduate Student, Department of Algebra and Geometry, Yaroslav-the-Wise Novgorod State University (Veliky Novgorod, Russian Federation), k.a.o_leksey999@mail.ru

\title{
ЧИСЛЕННОЕ ИССЛЕДОВАНИЕ ТЕЧЕНИЯ ВЯЗКОУПРУГОЙ ЖИДКОСТИ КЕЛЬВИНА-ФОЙГТА НУЛЕВОГО ПОРЯДКА В МАГНИТНОМ ПОЛЕ
}

\author{
С. И. Кадченко, А. О. Кондюков
}

В статье разработаны алгоритмы численного решения начально-краевой задачи течения вязкоупругой несжимаемой жидкости Кельвина-Фойгта в магнитном поле Земли. В работах Т.Г. Сукачевой, А.О. Кондюкова с помощью теории полулинейных уравнений соболесвкого типа доказана теорема существования и единственности решения указанной задачи. Производя дискретизацию, исходная начально-краевая задача преобразована к задаче Коши для систем обыкновенных нелинейных уравнений. Для получения численного решения задачи Коши использованы алгоритмы, основанные на явных одношаговых схемах типа Рунге-Кутты седьмого порядка точности с выбором шага интегрирования. Оценка контроля точности вычислений на каждом временном шаге осуществлялась по схеме восьмого порядка точности. По результатам контроля выбирался временной шаг. Вычислительные эксперименты показали высокую вычислительную эффективность разработанных алгоритмов решения исследуемых задач.

Ключевые слова: магнитогидродинамика, несжимаемая вязкоупругая жидкость, явные одношаговые формулы Рунге-Кутты, уравнения соболевского типа. 


\section{Литература}

1. Осколков, А.П. Начально-краевые задачи для уравнений движения жидкостей Кельвина-Фойгта и Олдройта / А.П. Осколков // Тр. МИАН СССР. - 1988. T. $179 .-$ C. $126-164$.

2. Hide, R. On Planetary Atmospheres and Interiors / R. Hide // Mathematical Problems in the Geophisical Sciences. V. 1. - Providence R.I.: AMS, 1971.

3. Сукачева, Т.Г. Фазовое пространство одной задачи магнитогидродинамики Т.Г. Сукачева, А.О. Кондюков // Дифф. уравнения. - 2015. - Т. 51, № 4. C. $495-501$.

4. Кондюков, А.О. Об одной модели магнитогидродинамики ненулевого порядка /А.О. Кондюков, Т.Г. Сукачева // XVI Всероссийский Симпозиум по прикладной и промышленной математике, летняя сессия. Челябинск, $21-27$ июня 2015. - Челябинск, 2015. - С. 75.

5. Кондюков, А.О. Квазистационарные полутраектории для обобщенной модели магнитогидродинамики / А.О. Кондюков // Тезисы международной конференции «Математика и информационные технологии в нефтегазовом комплексе», посвященной дню рождения великого русского математика академика П.Л. Чебышева. Сургут, 16 - 20 мая 2016. - Сургут, 2016. - С. 47.

6. Матвеева, О.П. Математические модели вязкоупругих несжимаемых жидкостей ненулевого порядка / О.П. Матвеева, Т.Г. Сукачева. - Челябинск: Издательский центр ЮУрГУ, 2014.

7. Флетчер, К. Вычислительные методы в динамике жидкостей. Т. 2. - М.: Мир, 1991.

8. Новиков, Е.А. Разработка алгоритмов переменной структуры для решения жестких задач: дис. ... канд. физ.-мат. наук / Е.А. Новиков. - Красноярск, 2014.

Кадченко Сергей Иванович, доктор физико-математических наук, профессор, кафедра прикладной математики и информатики, Магнитогорский государственный технический университет им. Г.И. Носова (г. Магнитогорск, Российская Федераu,я),kadchenko@masu.ru

Кондюков Алексей Олегович, аспирант, кафедра алгебры и геометрии, Новгородский государственный университет имени Ярослава Мудрого (г. Великий Новгород, Российская Федерачия), k.a.o_leksey999@mail.ru

Поступила в редакцию 27 мая 2016 г. 